\title{
Synthesis, Structural Characterization and Catalytic Activity of A Cu(II) Coordination Polymer Constructed from 1,4-Phenylenediacetic Acid and 2,2'-Bipyridine
}

\author{
Wang Li-Hua ${ }^{1 *}$, Liang Lei ${ }^{2}$, Wang Xin ${ }^{3}$ \\ ${ }^{1}$ College of Information and Engineering, Weifang University, Weifang 261061, P.R. China \\ ${ }^{2}$ School of Harbin Light Industry, Harbin 150040, P.R. China \\ ${ }^{3}$ Department of Chemistry, Qinghai Normal University, Xining 810008, P.R. China
}

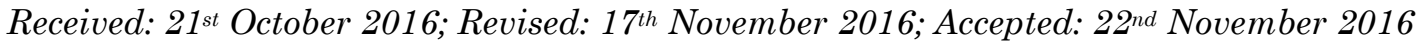

\section{Abstract}

In order to study the catalytic activity of $\mathrm{Cu}(\mathrm{II})$ coordination polymer material, a novel $1 \mathrm{D}$ chained $\mathrm{Cu}$ (II) coordination polymer material, [CuL(bipy) $\left.\left(\mathrm{H}_{2} \mathrm{O}\right)_{5}\right] \mathrm{n}(\mathbf{A 1})\left(\mathrm{H}_{2} \mathrm{~L}=1\right.$,4-phenylenediacetic acid, bipy $=2,2$ '-bipyridine), has been prepared by the reaction of 1,4-phenylenediacetic acid, 2,2'-bipyridine, $\mathrm{Cu}\left(\mathrm{CH}_{3} \mathrm{COO}\right)_{2} \cdot \mathrm{H}_{2} \mathrm{O}$ and $\mathrm{NaOH}$. The composition of $\mathrm{A} 1$ was determined by elemental analysis, IR spectra and single crystal X-ray diffraction. The results of characterization show that each $\mathrm{Cu}$ (II) atom adopts six-coordination and forms a distorted octahedral configuration. The catalytic activity and reusability of $\mathbf{A} \mathbf{1}$ catalyst for $\mathrm{A}^{3}$ coupling reaction of benzaldehyde, piperidine, and phenylacetylene have been investigated. And the results show that the $\mathrm{Cu}$ (II) complex catalyst has good catalytic activity with a maximum yield of 54.3\% and stability. Copyright (C) 2017 BCREC GROUP. All rights reserved

Keywords: $\mathrm{Cu}(\mathrm{II})$ coordination polymer; Preparation; Structural characterization; Catalytic activity

How to Cite: Li-Hua, W., Lei, L., Xin, W. (2017). Synthesis, Structural Characterization and Catalytic Activity of $\mathrm{A} \mathrm{Cu}$ (II) Coordination Polymer Constructed from 1,4-Phenylenediacetic Acid and 2,2'-Bipyridine. Bulletin of Chemical Reaction Engineering \& Catalysis, 12 (1): 113-118 (doi:10.9767/bcrec.12.1.735.113-118)

Permalink/DOI: http://dx.doi.org/10.9767/bcrec.12.1.735.113-118

\section{Introduction}

Metal coordination polymer materials have received more attention in recent years, because their novel structures and excellent properties such as catalysis, luminescence, magnetic and biological activity [1-5]. $\mathrm{Cu}$ (II) ion and podands containing carboxyl groups were used widely in the design of coordination polymer materials [6-8]. Propargylamines are versatile intermediates for organic synthesis and important structural elements of natural products and potential drug [9-12]. These com-

\footnotetext{
* Corresponding Author.
}

E-mail: wanglihua929@163.com

Telp.: +86-536-8785613, Fax.: +86-536-8785613 pounds have traditionally been synthesized by nucleophilic attack of lithium acetylides or Grignard reagents on imines or their derivatives $[13,14]$. However, these reagents must be used in stoichiometric amounts, are highly moisture sensitive, and require strictly controlled reaction conditions [14]. Therefore, the synthesis of the catalyst used in mild condition is very meaningful. Propargylamines were synthesized by three component one-pot coupling $\left(\mathrm{A}^{3}\right)$ reaction of aldehydes, alkynes and amines and the high potential of this reaction motivates many research groups to design new highly active and stable catalysts, mostly based on gold, silver, and copper species [15-20]. In this paper, we report a novel $\mathrm{Cu}(\mathrm{II})$ coordination polymer, 
namely, $\left[\mathrm{CuL}(\text { bipy })\left(\mathrm{H}_{2} \mathrm{O}\right)_{5}\right]_{\mathrm{n}}$ (A1), which displays a $1 \mathrm{D}$ chained structure. The catalytic activity and reusability of $\mathrm{Cu}$ (II) complex catalyst for $\mathrm{A}^{3}$ coupling reaction of benzaldehyde, piperidine, and phenylacetylene have also been investigated.

\section{Experimental}

\subsection{Materials and measurements}

The chemical reagents used in this paper are as following: 1,4-phenylenediacetic acid (A.R., Alfa Aesar), 2,2'-bipyridine (A.R., Alfa Aesar), $\mathrm{Cu}\left(\mathrm{CH}_{3} \mathrm{COO}\right)_{2} \cdot \mathrm{H}_{2} \mathrm{O}$ (A.R., Alfa Aesar), $\mathrm{NaOH}$, benzaldehyde (A.R., Alfa Aesar), piperidine (A.R., Alfa Aesar), phenylacetylene (A.R., Alfa Aesar), and 1,4-dioxane (A.R., Alfa Aesar).

Elemental analyses $(\mathrm{C}, \mathrm{H}$, and $\mathrm{N})$ were measured on an Elementar Vario III EL Elemental Analyzer. IR spectra were measured on a Nicolet AVATAR 360 infrared spectrometer in the $4000-400 \mathrm{~cm}^{-1}$ region. The crystal data of $\left[\mathrm{CuL} \text { (bipy) }\left(\mathrm{H}_{2} \mathrm{O}\right)_{5}\right]_{\mathrm{n}}$ were collected by a Bruker Amart CCD diffractometer.

\subsection{Synthesis of $\left[\mathrm{CuL}(\mathrm{bipy})\left(\mathrm{H}_{2} \mathrm{O}\right)_{5}\right]_{n}(\mathrm{~A} 1)$}

The $0.5 \mathrm{mmol}(0.9709 \mathrm{~g})$ 1,4-phenylenediacetic acid was dissolved in $15 \mathrm{~mL}$ $\mathrm{CH}_{3} \mathrm{CH}_{2} \mathrm{OH} / \mathrm{H}_{2} \mathrm{O}$ (v:v = 2:1) containg $1.0 \mathrm{mmol}$ $\left(\begin{array}{llllll}0.040 & \text { g }\end{array}\right) \mathrm{NaOH} . \quad 0.5 \quad \mathrm{mmol}(0.9933$ g $)$ $\mathrm{Cu}\left(\mathrm{CH}_{3} \mathrm{COO}\right)_{2} \cdot \mathrm{H}_{2} \mathrm{O}$ solid was added to the above solution, the mixture was refluxed for $1.5 \mathrm{~h}$ with stirring. Then $0.5 \mathrm{mmol}(0.078 \mathrm{~g})$ 2,2'-bipyridine was added, and the reaction mixture was continuously refluxed for $3.5 \mathrm{~h}$ with stirring. The light blue product was collected by filtration when the reaction mixture is cooled to the room temperature. The light blue crystals were obtained from evaporating the filtrate. From elemental analysis data, the calculated (\%) for $\mathrm{C}_{20} \mathrm{H}_{26} \mathrm{CuN}_{2} \mathrm{O}_{9}$ are: $\mathrm{C}, 47.81$; H, 5.18; N, 5.58. Found (\%): C, 47.50; H, 5.49; $\mathrm{N}, 5.67$. The selected IR bands $(\mathrm{KBr})$ were: $3281 \mathrm{~cm}^{-1}\left(\mathrm{H}_{2} \mathrm{O}\right), 1638 \mathrm{~cm}^{-1}$ (-COO-), $1486 \mathrm{~cm}^{-1}$ $(-\mathrm{C}=\mathrm{N}$ of bipy).

\subsection{Crystal data and structure determina- tion}

A single crystal of $\left[\mathrm{CuL}(\text { bipy })\left(\mathrm{H}_{2} \mathrm{O}\right)_{5}\right]_{\mathrm{n}}(\mathrm{A} 1)$ with dimensions of $0.22 \mathrm{~mm} \times 0.19 \mathrm{~mm} \times 0.18$ $\mathrm{mm}$ was mounted on a Bruker Amart CCD diffractometer equipped with a graphitemonochromatic MoKa $(\lambda=0.71073 \AA)$ for single crystal X-ray diffraction analysis. In the range of $3.01<\theta<25.01$, a total of 8019 reflections were collected and 3905 were independent with
$R_{\text {int }}=0.0588$, of which 3460 were observed with I $>2 \sigma(\mathrm{I})$. The structure was solved by direct methods with SHELXS-97 [21] and refined by full-matrix least-squares techniques on $\mathrm{F}^{2}$ with SHELXL-97 [22]. The most crystal data of A1 are given in Table 1.

\subsection{General procedure for the three com- ponent coupling reaction $\left(\mathrm{A}^{3}\right)$}

The benzaldehyde $(0.25 \mathrm{mmol}, 0.0265 \mathrm{~g})$, piperidine ( $0.30 \mathrm{mmol}, 0.0255 \mathrm{~g})$, phenylacetylene $(0.33 \mathrm{mmol}, 0.0337 \mathrm{~g})$ and 1,4-dioxane $(1.50 \mathrm{~g})$ were successively added to the $\mathrm{Cu}$ (II) complex (A1) catalyst $(0.070 \mathrm{~g})$, and then stirred at $120{ }^{\circ} \mathrm{C}$. After the reaction, the catalyst was removed from the solution by centrifugation at $10000 \mathrm{rpm}$ for 20 minutes. The yield of propargylamine is equal to the conversion of benzaldehyde, and was determined by using a by GC (GC1100, Capillary Column, SE-54) analysis. The recovered catalyst was thoroughly washed with 1,4-dioxane and used for the next run.

\section{Results and Discussion}

\subsection{Structural Description of [CuL(bipy) $\left.\left(\mathrm{H}_{2} \mathrm{O}\right)_{5}\right]_{\mathrm{n}}(\mathrm{A} 1)$}

The coordination environment of $\mathrm{Cu}$ (II) in $\left[\mathrm{CuL}(\text { bipy })\left(\mathrm{H}_{2} \mathrm{O}\right)_{5}\right]_{\mathrm{n}}(\mathrm{A1})$ is shown in Figure 1. There are one $\mathrm{Cu}$ (II) ion, one 1,4-phenylenediacetate ligand, one 2,2'-bipyridine ligand and five uncoordinated water molecules in the asymmetric unit. Each $\mathrm{Cu}(\mathrm{II})$ ion is sixcoordinated by four carboxylate oxygen atoms $(\mathrm{O} 1, \quad \mathrm{O} 2, \quad \mathrm{O} 3, \quad \mathrm{O} 4)$ from two different 1,4-phenylenediacetate ligands and two nitrogen atoms $(\mathrm{N} 1, \mathrm{~N} 2)$ from one 2,2'-bipyridine ligand to form a distorted octahedral coordination architecture. The selected important bond parameters of complex A1 are given in Table 2. The bond lengths of $\mathrm{Cu}-\mathrm{O}$ and $\mathrm{Cu}-\mathrm{N}$ in complex A1 fall in the 1.942(2)-1.951(2) and 1.993(3)2.001(3) $\AA$ regions, respectively, which are in accordance with ref. [23]. In complex $\mathbf{A} 1$, each 1,4-phenylenediacetate ligand adopts bidentate coordination mode with $\mathrm{Cu}(\mathrm{II})$. The 1,4-phenylenediacetate ligands bridge $\mathrm{Cu}$ (II) atoms into an infinite $1 \mathrm{D}$ chained structure (Figure 2 ).

\subsection{Catalytic studies}

The catalytic activity of $\mathrm{Cu}$ (II) complex was tested for $\mathrm{A}^{3}$ coupling reaction of benzaldehyde, piperidine and phenylacetylene (Figure 3). Figure 4 shows the catalytic activity and reusabi- 


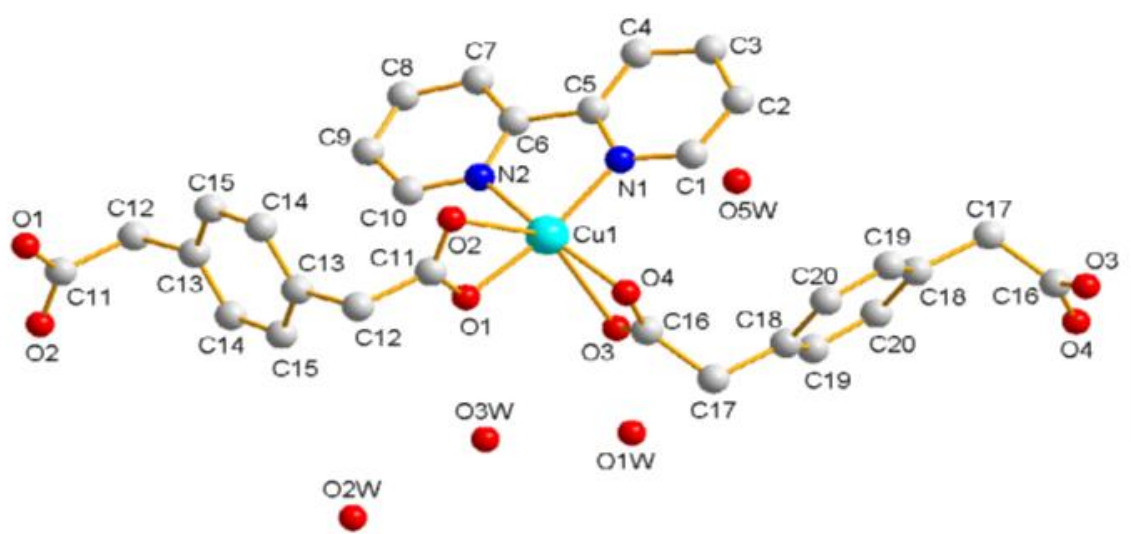

Figure 1. Coordination environment of $\mathrm{Cu}$ (II) center in $\mathbf{A 1}$

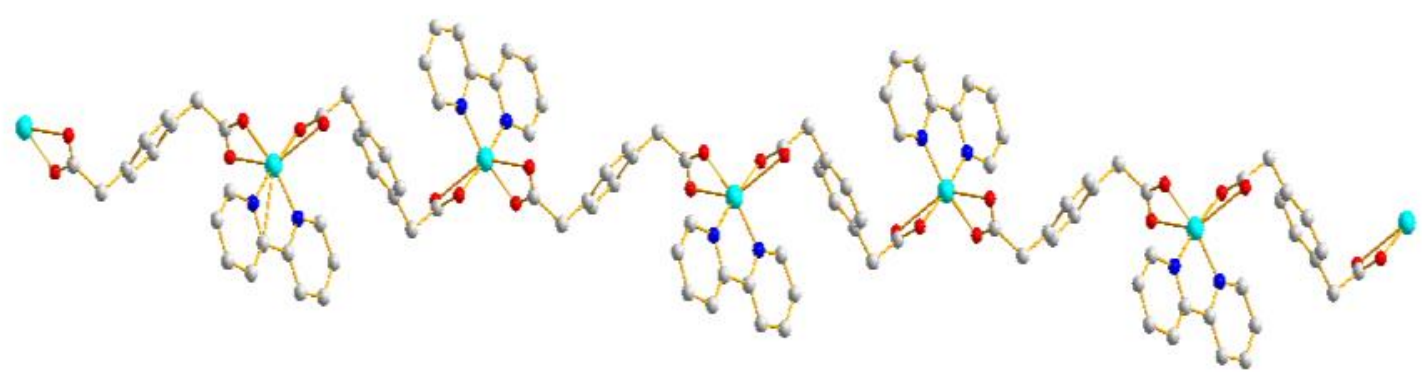

Figure 2. 1D chained structure of $\mathrm{Cu}(\mathrm{II})$ complex A1

Table 1. The most crystal data of A1

\begin{tabular}{ll}
\hline Empirical formula & $\mathrm{C}_{20} \mathrm{H}_{26} \mathrm{CuN}_{2} \mathrm{O}_{9}$ \\
Formula weight & 501.97 \\
Temperature/K & $293(2)$ \\
Crystal system & triclinic \\
Space group & $P-1$ \\
$a / \AA$ & $8.9701(18)$ \\
$b / \AA$ & $9.883(2)$ \\
$c / \AA$ & $13.418(3)$ \\
$\alpha /^{\circ}$ & $73.79(3)$ \\
$\beta /{ }^{\circ}$ & $78.99(3)$ \\
$\gamma^{\circ}$ & $86.36(3)$ \\
Volume/A & $1121.1(4)$ \\
$Z$ & 2 \\
$\rho_{\text {calcmg/mm }}^{3}$ & 1.487 \\
$\mu /$ mm $^{-1}$ & 1.027 \\
$S$ & 1.082 \\
$F(000)$ & 522 \\
Index ranges & $-10 \leq h \leq 9$, \\
& $-11 \leq k \leq 11$, \\
Reflections collected & $-15 \leq l \leq 15$ \\
Independent reflections & 8109 \\
Data/restraints/parameters & $3905[R(\mathrm{int})=0.0588]$ \\
Goodness-of-fit on $F^{2}$ & $3905 / 0 / 289$ \\
Final $R$ indexes $[I \geq 2 \sigma(I)]$ & 1.082 \\
Final $R$ indexes [all data] & $R 1=0.0632, w R_{2}=0.1603$ \\
\hline
\end{tabular}


lity of $\mathrm{Cu}$ (II) complex for $\mathrm{A}^{3}$ coupling reaction of benzaldehyde, piperidine, and phenylacetylene with 1,4-dioxane as solvent at $120{ }^{\circ} \mathrm{C}$. It can be seen that $\mathrm{Cu}(\mathrm{II})$ complex exhibited a good catalytic activity for $\mathrm{A}^{3}$ coupling reaction of benzaldehyde, piperidine, and phenylacetylene. At the initial stage of the $\mathrm{A}^{3}$ coupling reaction, the yield of propargylamines increases with the increasing of reaction time. Maximum yield of $54.3 \%$ was obtained within $5 \mathrm{~h}$ over $\mathrm{Cu}$ (II) complex catalyst, and then remained constant. After two successive cycles of the $\mathrm{Cu}$ (II) complex catalyst being extensively washed with 1,4-dioxane each, the yield of propargylamines

Table 2. The selected important bond parameters of complex A1

\begin{tabular}{cccc}
\hline Bond & Distance $(\AA)$ & Angle & $\left({ }^{\circ}\right)$ \\
\hline Cu1-O1 & $1.951(2)$ & O4-Cu1-O1 & $93.06(11)$ \\
Cu1-O4 & $1.942(2)$ & O4-Cu1-N1 & $92.97(11)$ \\
Cu1-N1 & $1.993(3)$ & O1-Cu1-N1 & $170.27(10)$ \\
Cu1-N2 & $2.001(3)$ & O4-Cu1-N2 & $168.05(10)$ \\
C16-O3 & $1.241(4)$ & O1-Cu1-N2 & $94.22(10)$ \\
C11-O2 & $1.221(4)$ & N1-Cu1-N2 & $81.17(10)$ \\
& & O2-C11-O1 & $122.9(3)$ \\
& & O3-C16-O4 & $121.9(3)$ \\
\hline
\end{tabular}<smiles>CC#Cc1ccccc1</smiles>

Figure 3. $\mathrm{A}^{3}$ coupling reaction of benzaldehyde, piperidine and phenylacetylene using $\mathrm{Cu}$ (II) complex as catalyst

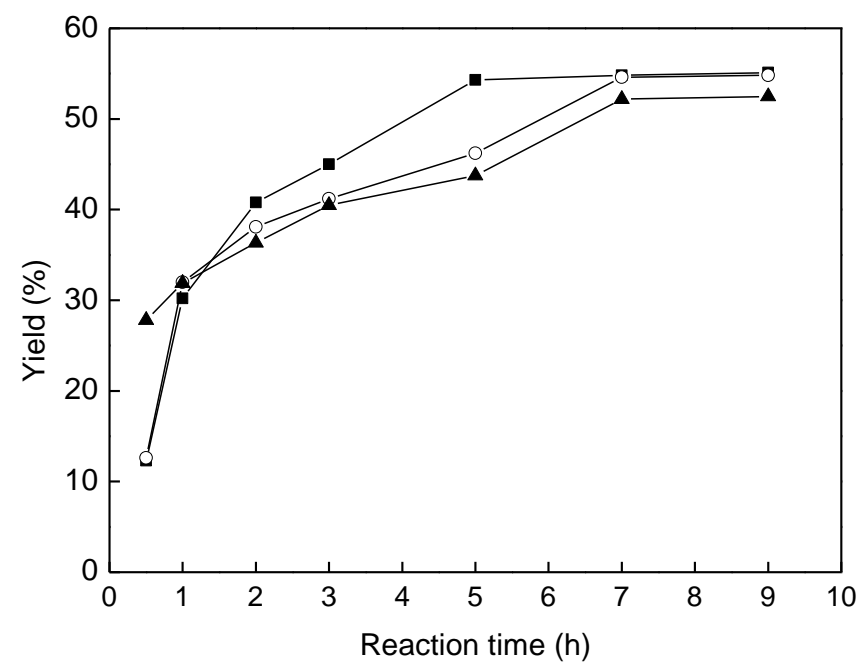

Figure 4. The catalytic activity and reusability over $\mathrm{Cu}(\mathrm{II})$ complex for $\mathrm{A}^{3}$ coupling reaction of benzaldehyde, piperidine, and phenylacetylene with 1,4-dioxane as solvent at $120^{\circ} \mathrm{C}$. (ロ) Fresh; (०) run1; (A) run2 
were $54.6 \%$ and $52.2 \%$ at reaction time of $7 \mathrm{~h}$, respectively. There is very slight drop in catalytic activity was found over $\mathrm{Cu}(\mathrm{II})$ complex for successive three uses in $\mathrm{A}^{3}$ coupling reaction of benzaldehyde, piperidine and phenylacetylene, so the $\mathrm{Cu}$ (II) complex catalyst has good stability. These features render the catalysts particularly attractive in the practice of propargylamines synthesis in an environmentally friendly manner.

\section{Conclusions}

In summary, a novel $1 \mathrm{D}$ chained $\mathrm{Cu}(\mathrm{II})$ coordination polymer has been synthesized. And its structure has been characterized by elemental analysis, IR spectra and single crystal X-ray diffraction. The catalytic activity and reusability of $\mathrm{Cu}(\mathrm{II})$ complex catalyst for $\mathrm{A}^{3}$ coupling reaction of benzaldehyde, piperidine, and phenylacetylene show that the $\mathrm{Cu}(\mathrm{II})$ coordination polymer catalyst has good catalytic activity and stability.

\section{Acknowledgement}

This project was supported by the National Natural Science Foundation of China (No. 21171132), the Natural Science Foundation of Shandong (ZR2014BL003), the project of Shandong Province Higher Educational Science and Technology Program (J14LC01) and Science Foundation of Weifang.

\section{References}

[1] You, L.X., Zhu, W.L., Wang, S.J., Xiong, G., Ding, F., Ren, B.Y., Dragutan, I., Dragutan, V., Sun, Y.G. (2016). High Catalytic Activity in Aqueous Heck and Suzuki-Miyaura Reactions Catalyzed by Novel $\mathrm{Pd} / \mathrm{Ln}$ Coordination Polymers Based on 2,2'-Bipyridine-4,4'dicarboxylic Acid as a Heteroleptic Ligand. Polyhedron, 115: 47-53.

[2] Chen, M.M., Li, H.X., Lang, J.P. (2016). Two Coordination Polymers and Their Silver(I) Doped Species: Synthesis, Characterization, and High Catalytic Activity for the Photodegradation of Various Organic Pollutants in Water. European Journal of Inorganic Chemistry, 2016: 2508-2515.

[3] Yuan, F., Zhang, L., Hua, H.M., Bai, C., Xue, G.L. (2017). Four New Coordination Polymers based on Carboxyphenyl- Substituted Dipyrazinylpyridine Ligand: Syntheses, Structures, magnetic and luminescence Properties. Journal of Molecular Structure, 1128: 385-390.
[4] Wang, X.P., Han, L.L., Lin, S.J., Li, X.Y., Mei, K., Sun, D. (2016). Synthesis, Structure and photoluminescence of Three 2D Cd(II) Coordination Polymers Based on Varied Dicarboxylate Ligand. Journal of Coordination Chemistry, 69(2): 286-294.

[5] Paul, M., Dastidar, P. (2016). Coordination Polymers Derived From Non-Steroidal Antiinflammatory Drugs for Cell Imaging and Drug Delivery. Chemistry-A European Journal, 22(3): 988-998.

[6] Zhao, S.N., Su, S.Q., Song, X.Z., Zhu, M., Hao, Z.M., Meng, X., Song, S.Y., Zhang, H.J. (2013). A Series of Metal-Organic Frameworks Constructed From a V-shaped Tripodal Carboxylate Ligand: Syntheses, Structures, Photoluminescent, and Magnetic Properties. Crystal Growth \& Design, 13(7): 2756-2765.

[7] Marino, N., Armentano, D., Mastropietro, T.F., Julve, M., Lloret, F., Munno, G. D. (2010). A Copper(II) Cytidine Complex as a Building Unit for the Construction of an Unusual Three Dimensional Coordination Polymer. Crystal Growth \& Design, 10(4): 17571761.

[8] García, F., Perles, J., Zamora, F., Amo-Ochoa, P. (2016). Rhodium and Copper 6methylpicolinate Complexes, Structural Diversity and Supramolecular. Inorganica Chimica Acta, 453: 574-582.

[9] Liu, L.L., Zhang, X., Gao, J.S., Xu, C.M. (2012). Engineering Metal-organic Frameworks Immobilize Gold Catalysts for Highly Efficient One-pot Synthesis of Propargylamines. Green Chemistry, 14: 17101720 .

[10] Li, P., Wang, L. (2007). A Highly Efficient Three-component Coupling of Aldehyde, Terminal Alkyne, and Amine via C-H Activation Catalyzed by Reusable Immobilized Copper in Organic-inorganic Hybrid Materials under Solvent-free Reaction Conditions. Tetrahedron, 63(25): 5455-5459.

[11] Dyker, G. (1999). Transition Metal Catalyzed Coupling Reactions under $\mathrm{C}-\mathrm{H}$ Activation. Angewandte Chemie International Edition, 38: 1698-1712.

[12] Liu, L.L., Tai, X.S., Zhang, N.N., Meng, Q.G., Xin, C.L. (2016). Supported Au/MIL-53(Al): A Reusable green solid Catalyst for the Threecomponent Coupling Reaction of Aldehyde, Alkyne, and Amine. Reaction Kinetics, Mechanisms, and Catalysis, 119: 335-348.

[13] Zhang, X., Corma. A. (2008). Efficient Three-component Coupling Reaction. Angewandte Chemie International Edition, 47: 4358-4361. 
[14] Murai, T., Mutoh, Y., Ohta, Y., Murakami. M. (2004). Synthesis of Tertiary Propargylamines by Sequential Reactions of in Situ Generated Thioiminium Salts with Organolithium and magnesium Reagents. Journal of the American Chemical Society, 126: 5968-5969.

[15] Borah, B.J., Borah, S.J., Saikia, K., Dutta, D.K. (2014). Efficient One-pot Synthesis of Propargylamines Catalysed by Gold Nanocrystals Stabilized on Montmorillonite. Catalysis Science \& Technology, 4(11): 40014009.

[16] Berrichi, A., Bachir, R., Benabdallah, M., Choukchou-Braham, N. (2015). Supported Nano Gold Catalyzed Three-component Coupling Reactions of Amines, Dichloromethane and Terminal Alkynes (AHA). Tetrahedron Letters, 56: 1302-1306.

[17] Liu, L.L., Tai, X.S., Liu, M.F., Li, Y.F., Feng, Y.M., Sun, X.R. (2015). Supported Au/MOF-5: A Highly Active Catalyst for Threecomponent Coupling Reactions. CIESC Journal, 66(5): 1738-1747.

[18] Villaverde, G., Corma, A., Iglesias, M., Sánchez, F. (2012). Heterogenized Gold Complexes: Recoverable Catalysts for Multicomponent Reactions of Aldehydes, Terminal Alkynes, and Amines. ACS Catalysis, 2(3): 399406.
[19] Wei, C., Li, Z., Li, C.J. (2003). The First Silver-Catalyzed Three-Component Coupling of Aldehyde, Alkyne, and Amine. Organic Letters, 5: 4473-4475.

[20] Tai, X.S., Liu, L.L., Yin, J. (2014). Synthesis, Crystal Structure of Tetra-Nuclear Macrocyclic $\mathrm{Cu}(\mathrm{II})$ Complex Material and Its Application as Catalysts for $\mathrm{A}^{3}$ Coupling Reaction. Journal of Inorganic and Organometallic Polymers and Materials, 24(6): 1014-1020.

[21] Sheldrick, G.M. (1997). SHELXL-97, Program for Crystal Structure Solution. University of Göttingen: Göttingen, Germany.

[22] Sheldrick, G.M. (1997). SHELXTL-97, Program for Crystal Structure Refinement. University of Göttingen: Göttingen, Germany.

[23] Gaur, A., Klysubun, W., Soni, B., Shrivastava, B.D., Prasad, J., Srivastava, K. (2016). Identification of Different Coordination Geometries by XAFS in Copper(II) Complexes with Trimesic Acid. Journal of Molecular Structure, 1121: 119-127. 